Original Research Paper

\title{
Director's Methods in the Kazakhstan Auteur Documentary Filmmaking
}

\author{
Aibarsha Muratbekovna Bozheyeva and Baubek Bauyrzhanuly Nogerbek
}

Kazakh National Academy of Arts Named After T. Zhurgenov, Almaty, Kazakhstan

Article history

Received: 02-03-2016

Revised: 29-04-2016

Accepted: 22-06-2016

Corresponding Author: Aibarsha Muratbekovna Bozheyeva

Kazakh National Academy of Arts Named After T.

Zhurgenov, Almaty,

Kazakhstan

Email: aya_b@mail.ru

\begin{abstract}
The article is focused on an important issue of art studying: Director's methods in the auteur documentary film creation. The objectives of this work are systematization of methods, study of their individual characteristics and the identification of common approaches to their application. The authors have relied on the works of philosophers, film theorists, art historians, psychologists, critics and the screen art researchers. As a conceptual framework, the authors have used such notions as the theory of "visual thinking"; film as a "text" and its "metatext in the otherness"; the "cinema" metaphor. The study is based on the examples of the director's methods in auteur documentary films made during the collapse of the USSR and the formation of independent Kazakhstan (19852005). The authors have studied the tendencies of correlation between the creator's techniques and the principle autonomy of directors' personal attitude. This article proves that the set of artistic methods can be considered as a single ideological system. The example of hermeneutic film analysis of the filmmaker S. Dvortsevoy has been given.
\end{abstract}

Keywords: Auteur Documentary Filmmaking, Director's Methods, Visual Thinking, Author's View, Object

\section{Introduction}

The article is devoted to the film director's methods in the auteur documentary. The purpose of this work is to prove that the set of artistic methods can be considered as a single ideological system. Specifically, the methods of Kazakhstani directors of art films made in the period from 1985 to 2005 are explored. It was at that time when documentary filmmaking gradually acquired authenticity, a risky aesthetics and opened new prospects with modern television and digital technologies and therefore became more democratic and accessible, separated from the journalistic genre, from the situational optical rhetoric and functional fixation of the circumstances learned by rote. A master list-canon (Samutina, 2002) of directors, whose work still determines the image of Kazakhstani auteur documentary cinematography, was formed.

The research is aimed at conducting a selection of films and directors; systematizing director's methods; identifying the individual characteristics of the methods; assessing how the period of acquiring authenticity is manifested in the work of directors and what is included in the scope of their cinematic attention; and determining the relationship between directors' world views and their methods.

The study of creative, technical and artistic aspects of preproduction, production and postproduction methods in directing, particularly in the field of auteur documentary filmmaking and director's methods, reveals the diversity of research directions (Rabiger, 2014). Voegelin (2014) used a sequential comparison of the auditory and visual among the methods of working with sound. Of most interest is her concept of «soundscape» as the sound genius loci. The S. Voegelin's concept of "soundscape" has been applied in the analysis of director S. Dvortsevoy's methods of working with sound. Klevan (2016) introduces the term estimated criticism, describes and justifies the criteria for selection and evaluation of film works. Popov (2015) describes the technological and social aspects of 3D digital filmmaking technologies. Sperling (2016), addressing the problem of the confrontation between art and media streams in the digital age, states that great art is defined by its inability to be reduced to pure ideology.

Additionally, we have considered research works dealing with the perception of the objective reality and 
its subjective transformation under the influence of different factors. Rutten et al. (2013) analyze the impact of documentary film on the collective memory. It is hypothesized that in the conditions of an empire, special properties of the media and the collective memory form the socio-political system of the empire and define post-imperial transformations. Bernard (2007) examines such aspects of documentary filmmaking as the theory of vision, visualanthropological problems and the relationship of visual anthropology, in particular referring to ethnographic films and experimental cinema. McGann (2014) writes that in the era of digital art, old notions of "textuality" are not adequate for describing its new types such as electronic literature and various forms of digital media, including cinema and art installations. The text is understood in a broad sense. It is determined by such properties as the readability and interpretability. Stoddard (2016) considers cinema as a subject of political investigation, develops the meaning of "political modernism" and introduces the notion of "fidelity to the event". The works of M. Stoddard have influenced the analysis of the methods of director Asiya Baigozhina, who made a film dedicated to an anti-Soviet regime uprising in Almaty in December 1986. Thirty years later, she shot the second film dedicated to the same event with the same characters.

Memory studies by Sarkisova and Shevchenko (2014; Rutten et al., 2013) have been taken into account in conducting in-depth unstructured interviews of Kazakhstani directors.

Graham (2012; Benjamin, 2013; Chernyshova, 2013; Kozlov, 2013; Gürsel, 2014; Sarkisova and Shevchenko, 2014) study the individual properties of the memory, as well as artistic voids (lacunae) in creative works, reveal the existence of different historical and cultural ways of dealing with the past and develop one of the most interesting areas of memory studies-"political regime memories" ("mnemonic modes"). The collection of articles "Silence, Screen and Spectacle: Rethinking Social Memory in the Age of Information and New Media" (2014) analyzes the global "culture of remembrance" of the modern world, which is constantly being transformed with the advent of new media. It investigates the methods by which the past is told, represented, expressed on screen, broadcasted on the radio and television and then placed in Facebook and Twitter and considered in new contexts.

The literature review confirms the existence of the individual characteristics and contradictions in the perception of the same reality by different directors. However, contemporary scientific researches that consider director's methods in documentary filmmaking in a systemic way have not been found. The relevance of this work lies in the fact that for the first time, the authors have systemically traced the tendencies of correlation between preferences in the selection of objects and methods and the principal autonomy of director's personal attitudes. It is suggested to apply the "methodology of the point of view" as a system of director's auteur methods in the analysis of creative works. Further, for the first time, this paper studies and classifies auteur artistic methods on the basis of the works of Kazakhstani documentary filmmakers in the period of the independent state formation and development.

Criteria for the selection of director's documentary films are the following:

- The auteur uniqueness of director's methods

- The originality of the film idea

- The singularity of artistic language

- The author's vision of the character and his environment

We have chosen the following documentary filmmakers for the study: Asya Baigozhina, Bakhyt Gafu, Igor Gonopolskyi, Sergey Dvortsevoy, Elena Prokoptseva and Vladimir Tyulkin. Documentary movies have been watched (5-10 films of each director). We structured director's methods on preproduction, production and postproduction stages, analyzed the methods and identified the general tendencies. The following techniques have been selected for our research: Hermeneutic method, structural analysis and in-depth (unstructured) interview. The totality of these methods has allowed clarifying many aspects of the work of a documentary director as well as finding out the deliberation (or instinctiveness) of his method selection.

Director's methods as a whole form a system of the director's individual work in film creation. Each system has unique features that are directly related to the personality of the director, his artistic preferences, moral attitudes, religious affiliation, ideology and philosophy. General tendencies that dominate in the post-Soviet cinematograph reflect the peculiarities of formation of a new political system, a low level of censorship, the development of technical capabilities of production, the level of culture of the viewer's perception, etc.

\section{Materials and Methods}

\section{Theoretical Basis}

The works of the following philosophers, art historians, film critics, cinema theorists, screen art researchers, sociologists and psychologists from the last century to the present day make the theoretical basis of this article:

- Theorists-pioneers: Eisenstein (1964a; 1964b; 1964c; 1964d; Truffaut, 1985; Arnheim, 1994; 
Barthes, 1994; Lotman, 1998), philosophers Derrida (2000; Deleuze, 2004)

- Modern scientists: Abikeeva (2001; Sturhen and Cartwrigt, 2001; Tarkovsky, 2002; Yampolsky, 2002; Bignell, 2002; Samutina, 2002; Galloway et al., 2007; Koppel, 2007; Gurganov and Dolokhov, 2002; Ebert, 2011; Bernard, 2007)

- Research works published in the last three years: Benjamin (2013; Chernyshova, 2013; Bredehoft, 2014; Badiou and Tarby, 2013; Popov, 2015; Flaxman, 2016; Corrigan, 2016; Flisfeder, 2016; Frey, 2016; Sayad, 2016; McGann, 2014) and others

The auteur style, the auteur manner and the original director's view of the subject are aspects of the unique director's visual thinking and are manifested through the use of individual methods in the work on the film creation. The auteur tendency in the world of art documentary cinema began in the earliest days of the era of cinema and is associated with such names as Dziga Vertov, Robert Flaherty, Sergei Eisenstein and many others. Since the appearance of the "French New Wave" in the $1950 \mathrm{~s}$, critics of the "Cahier du Cinema" magazine started using terms such as "auteur theory", "auteur cinema", "auteur policy." They laid the solid foundations of the "auteur theory" and the cinematographic science in general, learning to analyze in an integrated manner such components of director's "authorship" as a visual style, favored ideas, stories, actor types, genre elements, means of expression of "the author's point of view", etc. (Truffaut, 1985).

The auteur theory, which has been challenged by film critics, including the Roland Barthes's essay Barthes (1967), is experiencing a rebirth. Heehs (2013) in his study "Writing the Self" defines the last three historical periods in the development of the auteur theory:

- "Search for authenticity" (existentialism, the middle of the twentieth century)

- "Death of the subject" (post-structuralism and grammatology, the end of the twentieth century)

- "Subject is dead, long live the subject" (1985-2010)

\section{Text and Metatext}

Bredehoft (2014) argues that in its essence, a text artifact (for example, the "Beowulf" manuscript and "The Canterbury Tales") is one of the kind, unique and not designed to be copied. Bredehoft traces the evolution of the text to contemporary digitized, so-called "visible" text and hypertext.

In the philosophical work of Gilles Deleuze "Logic of Sense" visual component of the film may acquire an extremely important and sometimes absolute significance. This is proved, in particular, by the fact that in the modern philosophy, the notion of "text" has lost its initial verbal meaning (Deleuze, 2004).

According Deleuze, if the film is a text, there is metatext of this film in the otherness. As Jacques Derrida wrote, there is something beyond language that depends on the interpretation (Derrida, 2000).

Auteur filmmaking is a system and this system is connected with the audience and with the education of the audience and with the development of senses, as well as with the development of the common culture. The reader acts not as a consumer but as a producer of the text (Barthes, 1994).

\section{Theory of Visual Thinking}

Tarkovsky (2002) wrote in his "Sculpting in Time" about art image that it is indivisible and elusive, dependent upon our consciousness and on the real world which it seeks to embody.

The rapid development of cinema and its total penetration into all areas of life, thanks to television and the internet, has gradually transformed it into one of the most powerful means of formation of the mental world of modern man. The influence of this entirely new phenomenon of mental and cultural life gave rise to radical changes in the world of philosophical and aesthetic thought.

The theory of visual thinking of the American aesthetician and art psychologist Arnheim (1994:352) is based on the fact that the perception of art is not a passive act and visual images are not illustrations of the author's thoughts, but the final manifestation of his thinking activity. Thus, in the middle of the XX century, Arnheim introduced a new term into the academic practice: "visual thinking".

\section{“Cinema” Metaphor}

The documentary film is not an objective reality and each director creates a subjective image of the man/the outside world, using the particular methods. This position has become the approach basis in this study. The metaphor of "cinema" expresses the perception of the author-director (and the audience) through the "internal movie" (the choice of the director, the subjective reality) and "external movie" (the so-called objective reality) (Gurganov and Dolokhov, 2002).

"Internal movie" (or "internal film") of director determines the external "reality", i.e., the things chosen by the director. Thus, the director makes the viewer see the character/the outside world the way he sees it himself and in order to achieve it, the director uses certain methods. It should be noted that, in spite of the author's permissible violence in director's imposition of his own vision on the audience, we have to remember that every viewer is watching his own movie, paying attention in the movie to something specific, being blind to the 
things strange to his perception. He interprets images, lacunae, allusions in his own way.

The perception of the same family archive pictures by different generations exhibits the "post-memory" (Etkind, 2013) within which the scenes of Soviet history (collectivization, industrialization, the Great Patriotic War etc.) are depicted. By exploring this "post-memory" of three-four family generations, one can trace back the system of intra- and inter-generational transfer of traumatic knowledge and experience.

It was Alain Robbe-Grillet, the French writer and director, the founder of the direction known as a "new novel", who noticed that a new type of audience appeared. If the former audience tried to build a kind of Descartes' scheme while watching the film, i.e., as much linear and rational as possible, the new type audience, being tired of the old forms, is looking in the movie for things that correspond to the total movie of his consciousness (Robbe-Grillet, 2000: 285) and this internal film of our consciousness presents the fragments of the real, the past and even the future with the same degree of essence.

The idea of "internal movie" determines the director's choice. It is believed that internal movies influence the thoughts, emotions and sensations of the man. We even can go ahead and assume that the internal movie determines an external "reality". Thus, the authordirector of the documentary creates an image of the object through his "internal movie", very personal, subjective, which confirms the idea that no creative product can claim to be strictly objective, as everyone is different and sees the world and the man in his own way. Auteur vision/auteur point of view/director's internal film is manifested through the following:

- Interpretation of the script (subject, conception, idea)

- During the film shooting: Through the selection of the camera angle, distance to the object, composition, light, color, shot frame size, camera movements, arrangement of a scene, speed, rhythm, dynamics, motion in the shot

- During the montage: Through material selection, influence on the meaning by certain types of montage, musical-sound background, use of a particular text in the shot or behind the scenes

- During the film demonstration: Through the influence on the viewer's subconscious by working with the space, time, visual image, sign system

- $\quad$ Text and metatext, at last

\section{Hermeneutic Method}

Any audiovisual work, in this case, any documentary film is considered by the researcher as a text. Adequate understanding of the various texts and their interpretation is one of the most difficult tasks facing the analyst. But it is advisable to use the hermeneutics in the case when we are dealing with really complex, confusing philosophical or psychological films.

In this method, it is important to master the art of understanding of another person's world, entering such world and have the ability to feel empathy and compassion (Shalabayeva, 2012: 154-160).

\section{Structural Analysis}

Structural analysis is based on the sign systems, thus it appears to be closely related to semiotics (the science of sign systems) and semantics (the scientific study of meaning). Structuralism tends to be hermetic, i.e., the enclosed consideration, when the subject of analysis is the circularity of the system. Structural analysis may consider the text (the film or text screen work) as an organized set, as a system of elements. It allows to explore film as a system of methods, divide the creative product into segments, view it from different angles and at the same time, get inside the product without destroying its integrity (Shalabayeva, 2012).

Principles of structural analysis are the following:

- Division into elements (color, light, time, space, etc.)

- Study of the separate elements of the system and their relationships, integrity consisting of elements;

- Synchronous approach, when the subject of study is not the history of the creative product, but its structure

\section{In-Depth Interview}

Interviews with filmmaking practitioners play a very important role for a film critic (Buckland, 2016). This is a technique used to understand the complex behavior of the respondent without commentary dictate, narrowing the scope of the study. This type of interview is more like an informal conversation. The conversation is developed in the framework of the theme proposed by the researcher. The researcher asks questions and based on respondents' answers, he tries to obtain from them as much information as possible, to find out his opinion, in other words, "to dig into his soul". The reason why this method has been chosen for the study is the possibility in this kind of interview to determine exactly which techniques in films were deliberately scheduled by the director and which ones were used by him unconsciously and this is extremely important for this study: To determine the extent to which the creativity is an aesthetic activity predetermined by the competent consciousness.

Questions for the interview should be: Detailed and penetrating deeply into the studied subject; based on the read literature and watched movies; based on the selected theory; based on the experts' own logic, 
experience and advices; during the interview, the following aspects are analyzed and taken into account: Experience/behavior, opinion/values/knowledge/facts, biographical characteristics of the respondents. The following steps were used for the study itself:

- Watching and study of auteur documentary film of four or five well-known documentary filmmakers (3-6 films)

- Study of literature (critiques, interviews, works, statements the directors themselves) related to the directors themselves and the movies watched by the researcher of this study in order to better understand and prepare for the in-depth interview

- In-depth (unstructured) interview with directors (in general, 3-5 hours each, divided into sessions)

- Interview transcript and analysis

Topics for Unconstrained In-Depth Interviews with Film Directors

- Identifying features of auteur documentary cinema.

- A list of auteur documentary film directors according to the respondent:

- International documentary films (between 3 and 10 directors)

- Kazakh documentary films in the period from 1985 to 2015 (between 3 and 5 directors)

- Cultural, spiritual and aesthetic installations that are characteristic for the respective directors

- Various factors that influence the work methods of the respondent:

- Events linked to his or her personal life (childhood, family, relatives, friends)

- Events linked to the life of friends/ acquaintances/ strangers

- Historical events

- Political events

- Social events

- Natural phenomena

- Events of manmade character

- Events of metaphysical character

- Other

(Example: Please explain in detail what influence the fall of the Soviet Union and newly acquired independence of Kazakhstan did have on the theme of the film and the choice of its main characters)

- What importance do you put on the visual component of a documentary film? (Does the visual component of the movie carry a particular importance in your work?)
- What influences the creation of the initial story and/or idea? (starting point of the film development):

- A particular event (see point 4.)

- Memories and personal experience of friends, acquaintances and strangers

- Influence made by movies of other directors

- Books

- Works in other art forms (photography, painting, music, etc.)

- Imprinting

- What methods do you apply in the pre-production of the movie:

- Initial story, idea

- Search of a theme

- Collection of information

- Collection of material

- Study of the object

- Screenplay writing

- Visual conception of the movie

- Search for metaphors, allusions, semiotics

- Storyboard

- Space-time conception of the movie

- Style, tempo-rhythm, atmosphere of the movie

- What cinematic techniques do you use when working on the visual conception of the film:

- Style of the shoot (working on static and dynamic with the cameraman)

- Working with objects - distance of shots, camera angles, accents, etc.

- Style, atmosphere (size and depth of the shot, framing, light, color)

- Work methods with subjects in the shot (observation, provocation, recreation of events, etc.)

- Work methods with subjects during an interview process (placement of camera, camera angle, distance to the interviewee, position of the interviewer, size and volume within the frame and background)

- Work with details

- Semiotics, metaphors, artistic image

- Work with sound (dialogue, noise, music, tempo-rhythm)

- What artistic methods do you apply in the film editing process?

- Influence on the idea of the recorded material (changes to the initial story)

- Composition of the movie

- Rhythm of the movie 
- Working with time within the movie

- Atmosphere of the movie

- Working with colors and light

- Choice of text in the interviews

- Symbolic/ artistic image sequence of the movie

- Utilization of metaphors

- Utilization of semiotics

- Utilization of sound in the movie: Non-diegetic sound like narrator's commentary, music, noises

- According to the theory of visual thinking, the perception of art-not as a contemplative creative process, but rather as an active one, is analogous to intellectual cognition. Artistic methods for the visual conception of the movie are the final manifestation of the author's thought. What is characteristic for the surveyed director:

1. Perception of landscape (every nation has its own signature landscape)

2. Chronotopic perception of the world (representing his or her time and generation)

3. Perception of the world influenced by national, religious, etc. affiliation

4. Perception of the world through the eyes of the main character

5. Other

- In terms of influence of art on the human, what has a bigger impact - history or mystery? (methods)

\section{Results}

The analysis of the interviews has revealed the following in the director's methods:

- Use of auteur director's methods in the film dramaturgical structure

- Use of auteur director's methods in the work on the film form

- Use of auteur director's methods in the film shooting (visual style: camera angle, closeness of shot, shot composition, light and color in shot, movement of the camera)

- Mythologem creation through the choice and selection of material, myth enhancement through the use of auteur director's methods

- Use of auteur director's methods in montage to create a cinematic time and space

- Use of auteur director's methods in the sound and music score of the film

- Auteur methods in the use of special visual effects and computer graphics

- Methods of work with the audience at the "textmetatext" level (allusions, reminiscences, citations, metaphors, semantics and semiotics, images)
When structuring director's methods, the authors of the study divided them into the following conventional categories:

- Methods used in the interview with the character (sync) and direct shooting of the character in action (the character is in shot)

- Methods of displaying the character's world (his visual environment: Atmosphere, landscape, home, ambiance, objects, people, animals, etc.)

- Stylistic methods (manner of filming, editing methods, light/color/sound solution in the film)

- Methods of working with the time (slowing down, quickening, resolution, etc.)

- Methods of working with the space (shot frame size, camera movement, etc.)

- Methods of working with the imagination of the viewer (creation of lacunae, allusions, reminiscences)

- Methods of creation/complement of the character's image: Use of opinions, statements of other people, representation of relationship of the character with the people (interviews with people who talk about the character and so on.)

- Methods of artefacts using (i.e., things related to the character: His diaries, writings, products of the activity, as well as works of art, chronicles footage, citations to create analogies, allusions, imagery)

- Conflict as the method (montage, film structure, colour, light and sound solution in the film, dramaturgical development)

- Shooting scenes and shots as methods of fiction films, used in the documentary ("fact reconstruction" technique)

- Use of visual effects as a method

- Montage methods

Artistic focus of the hermeneutical method makes it possible to use many different layers, embedded in the subconscious of the director, his creative baggage, personal experience. The hermeneutic analysis of films in conjunction with in-depth interviews confirms the fact that it is difficult to determine for the director himself, where he works consciously and where he acts subconsciously. We have revealed the dependence of artistic methods use of subjective vision of the director. For example, after the fall of the Soviet regime, some directors have continued to move (perhaps much bolder) in the direction of the complementary retrospective biographical genre (Igor Gonopolskyi, Elena Prokoptseva), while others (Asiya Baigozhina, Bakhyt Gafu) realized the protest in the evolutionary impulses of artistic reflection. The thematic, religious, semiotic and stylistic preferences have been most clearly manifested in the works of Vladimir Tyulkin and Sergei Dvortsevoy. 
Hermeneutical analysis has been illustrated on the art works of Sergey Dvortsevoy (documentaries: "Happiness" (1995), "Bread Day" (1998), "Track" (1999), "In the Dark" (2004)). Priority elements of cinematographic writing of Sergey Dvortsevoy are the following:

To shoot without infringing on the authenticity of what is happening. Not to impose in any way on the landscape the auteur violent eye-catching tricks, gags, symbolic connotation, montage expression not corresponding to the temperament and temperature of the outdoor material and environment. For example, a shot from the film "Happiness", filmed using the observation method. A child in a yurt drinks some milk and falls asleep, without noticing the camera.

To always use the final background noise producing the cathartical effect, culmination password. For example, the twang of wheels covered with ice of the grain wagon pushed towards the railway overpass by stoop shouldered pensioners in heavy vests in the "Bread Day" movie.

To "scar up" microscopically closely with camera, in fact, minor details of the external environment.

The tendency to duplicate the same episode, correlate it, echoing it not for tempo-rhythmic savouriness, but with the aim to ensure cinematic structure integrity and reasonableness by means of shaping rondo: A deep, circular panorama of the steppe from the left to the right and in the opposite direction, from the right to the left (the film "Happiness").

Not to forget about multilingualism of the TurkoSlavic air. There is Kazakh, Uzbek, Russian, popular language, off-camera neutrality of the literary language, profanity, dialect.

All of the above is summarized in the unity of cinematic narrative aimed at productivity of methods of cinematographic writing described above. Sergey Dvortsevoy is among those directors and authors, whose works are distinguished by similarity and closed nature of the form, constancy of philosophical motifs and artistic tools of their representation.

The study revealed the following general tendencies in the work of various directors of the auteur documentary film.

The director is in a state of choice throughout the process of working on the film: The choice of idea, character, environment, etc. This choice is individual and is related to the director's philosophical, moral and creative principles, i.e., to his subjective vision and mindset. It is as per the director's decision that a particular method is used.

The director relies upon the material, follows the facts but may use them at his own discretion. In this case, the word "material" means everything that is shot or connected with the character: The character himself, his entourage and the products of his activity (his diaries, works, deeds, testimony of others, myths, etc.). Following the material as the objective reality, the director can choose only the things he finds necessary for the film and doing so he can express his subjective vision.

In the movie, the director creates a special space and time, which function under the laws different from those in the real time and space. Through various methods, the director manages the time and space in the film.

The authors of the study were based on the theory of constructivism. According to this theory, the director's methods in the documentary film can be classified, but each director's method (the way of shooting or editing, shot composition, perspective, color and light solution) is a subjective choice of the director, not to mention the choice of idea, character and specific manifestations of the surrounding world.

\section{Discussion}

The article presents, for the first time, the interim results of the doctoral thesis of A.M. Bozheyeva. Some findings of the thesis have been presented in the special course "Directing the documentary" at the Academy of Film and Television faculty of the "Turan" University and reported at the international scientific conferences at the T.Zhurgenov Kazakhstan National Academy of Arts (Almaty), "Turan" University (Almaty) and St.K.Ohridski University (Sofia) in 2014-2015.

During the author's methods study, it is necessary to take into account that the filmmaker expresses his subjective opinion regarding the object and is always consciously or subconsciously in the process when choosing:

- A specific character

- A specific idea

- A specific event (or events)

- Specific questions to be made in the interview with the character/a specific text is read

- A specific environment/context in which the character is

- Specific lacunae in the film space created by means of various montage methods

- A specific artistic language that creates the imagery and is based on the auteur imprinting

- Specific allusions, reminiscences and citations;

- Specific semiotics, etc.

In order to understand why the director took a particular decision, used one method or another, it is necessary to ask in the interview the questions based on:

- Knowledge of the director's biography 
- Knowledge of his artistic/taste/stylistic preferences

- Knowledge of his priorities/aspirations/phobias in various spheres of life

- The read literature

- The watched movies

- The selected theory

- The one's own logic

- The expert's experience and advices

The results of this study may be useful for in-depth study and understanding of the director's complex creative process. The elaborated methodical approaches may be used as a tool to study of director's methods in both documentary and fiction film.

\section{Conclusion}

This article studies and classifies, for the first time in the last fifteen or twenty years, the auteur artistic methods by exploring the works of Kazakhstani documentary filmmakers in the period of 1985-2005. The constructivism theory has allowed researchers to demonstrate that any director's method is a result of the subjective choice of the director. One of the chosen research methods (hermeneutic) allowed penetrating into the deep and individual processes of director's creativity, gaining a greater understanding of their ethical, aesthetic, philosophical and other criteria. It has been found that the work on the film is a complex process, both conscious and subconscious, based on knowledge of the profession, the intellectual level of the director, the psycho-physical characteristics of his personality, his life experience and creative intuition.

Structural analysis allowed classifying the director's methods and defining common approaches to the various directors. The study has shown that the director's methods used in the auteur documentary film are extremely subjective and affect practically all the components and elements of the film (form, structure, style, methods of filming and editing, visual solution, light, color, sound, imagery and others). Review of the literature on a selected subject has helped researchers to identify topics for the interview. The in-depth unstructured interviews with directors have covered the issues related to the drama, form, structure, shooting and edition of documentary films. In the use of methods, the director is mainly guided by his own criteria:

- Moral and ethical

- Philosophical, worldview

- Aesthetic, taste
Director's methods as a whole form a system of director's individual work the on the film creation. Each system has unique features that are directly related to the personality of the director, his artistic preferences/moral attitudes /religious affiliation/ideology/philosophy.

Scientific novelty of the paper lies in the fact that no significant works have yet been conducted in order to study artistic director's methods as a single ideological system that appeared in the period of formation and development of the independent state of Kazakhstan. General tendencies that dominate in the post-Soviet cinematograph reflect the peculiarities of formation of a new political system, a low level of censorship, the development of technical capability of production, the level of culture of the viewer's perception, etc.

Conclusions of the study:

- There is a relationship between the application of artistic techniques and an individual director's vision of reality

- The set of artistic practices of directors of auteur documentary films can be viewed as a single ideological system

- The presence of a unified methodology of auteur practices ("the methodology of view") is the main tendency among directors of auteur documentaries

The paper presents the interim findings of the ongoing doctoral research of A.M. Bozheyeva "Documentary filmmaking: Object and methodology of view". We have used the interviews with the directors conducted by the author A.M. Bozheyeva in 2003-2004 and in 2015-2016, as well as her personal experience of working in the documentary cinematograph domain. The author plans to continue the studies of the Kazakhstani documentary cinema in the next period, from 2005 to 2015.

\section{Acknowledgment}

We thank film directors Asya Baigozhina, Bakhyt Gafu, Igor Gonopolskyi, Sergey Dvortsevoy, Elena Prokoptseva, Vladimir Tyulkin. Special thanks to B.N. Nusipzhanova, Rector of Kazakh National Academy of Arts named after T. Zhurgenov, R.A. Alshanov, Rector of "Turan" University, A. Martonova, PhD of Arts for their support in scientific work.

\section{Funding Information}

This work was supported and funded by the Ministry of Education and Science of the Republic of Kazakhstan, Ministry of Culture and Sport of the Republic of Kazakhstan and Kazakh National Academy of Arts named after T.K. Zhurgenov. 


\section{Author's Contributions}

Aibarsha Muratbekovna Bozheyeva: Developed the plan of the research and carried out the study, analysis and writing of the manuscript.

Baubek Bauyrzhanuly Nogerbek: Scientific adviser, helped with research and searching the literature.

\section{Ethics}

This article is original and contains unpublished material. The authors confirm that there are no ethical issues involved.

\section{References}

Abikeeva, G., 2001. Central Asian cinema. IREX, Almaty.

Arnheim, R., 1994. The New Essays on the Psychology of Art. 1st Edn., Prometei, Moscow.

Badiou, A. and F. Tarby, 2013. Philosophy and the Event. 1st Edn., Polity, Cambridge, UK., ISBN-10: 0745653952, pp: 160.

Barthes, R., 1967. Death of the author. Aspen.

Benjamin, W., 2013. On some motifs in Baudelaire.

Bernard, S.C., 2007. Documentary Storytelling: Making Stronger and More Dramatic Nonfiction Films. 1st Edn., Taylor and Francis, ISBN-10: 0240808754, pp: 379.

Bignell, J., 2002. Media Semiotics. 2nd Edn., Manchester University Press, London, ISBN-10: 0719062055, pp: 256.

Bredehoft, T.A., 2014. The Visible Text: Textual Production and Reproduction from Beowulf to Maus. 1st Edn., Oxford University Press, ISBN-10: 0199603162, pp: 192.

Buckland, W., 2016. The film critic between theory and practice; (Or: What every film critic needs to know. Film Criticism.

Chernyshova, N., 2013. Soviet Consumer Culture in the Brezhnev Era. 1st Edn., Routledge, London, ISBN-10: 1135046271, pp: 280.

Corrigan, T., 2016. The Glare of Images and the Question of Value. Film Criticism.

Deleuze, G., 2004. Cinema. Translated from French by B. Skuratov. Ad Marginem, Moscow.

Derrida, J., 2000. Derrida about the others in grammatology.

Ebert, R., 2011. Roger Ebert's Movie Yearbook 2012. 1st Edn. andrews McMeel Publishing, London, ISBN-10: 1449408133, pp: 792.

Eisenstein, S., 1964a. Speech to the All-Union Creative Conference of Workers in Soviet Cinema (1935). 1st Edn., Iskusstvo, Moscow.
Eisenstein, S., 1964b. The Fourth Dimension in Cinema. 1st Edn., Iskusstvo, Moscow.

Eisenstein, S., 1964c. Vertical Montage. 1st Edn., Iskusstvo, Moscow.

Eisenstein, S., 1964d. Theoretical Studies and Articles. 1st Edn., Iskusstvo, Moscow.

Etkind, A., 2013. Warped Mourning: Stories of the Undead in the Land of the Unburied. 1st Edn., Stanford University Press, Stanford, ISBN-10: 0804785538, pp: 320.

Flaxman, G., 2016. The dysfunction of criticism at the present Time. Film Criticism.

Flisfeder, M., 2016. Ideology critique and film criticism in the new media ecology. Film Criticism. DOI: $10.3998 /$ FC. 13761232.0040 .110

Frey, M., 2016. Netflix crit in the twenty-first century. Film Criticism.

Galloway, D., K.B. McAlpine and P. Harris, 2007. From Michael Moore to JFK reloaded: Towards a working model of interactive documentary. J. Media Pract., 8: 325-339. DOI: 10.1386/jmpr.8.3.325_1

Graham, A., 2012. 'Immersion in time': History, memory and the question of readability in the films of Aleksei German. Stud. Russian Soviet Cinema, 6: 117-216. DOI: $10.1386 /$ srsc.6.2.177 1

Gurganov, V. and V. Dolokhov, 2002. Technology of Success. 1st Edn., Piter, St. Petersburg.

Gürsel, Z., 2014. Framing Zarqawi: Afterimages, Headshots and Body Politics in a Digital Age. In: Double Exposure: Memory and Photography. Shevchenko, O. (Ed.), Transaction Publishers, Rutgers, N.J., pp: 65-90.

Heehs, P., 2013. Writing the Self: Diaries, Memoirs and the History of the Self. 1st Edn., Bloomsbury, New York, ISBN-10: 1441168281, pp: 288.

Klevan, A., 2016. What is evaluative criticism. Film Criticism. DOI: 10.3998/fc.13761232.0040.118

Koppel, G., 2007. Documentary-the evocation of a world. Media Pract., 8: 305-323. DOI: $10.1386 /$ jmpr.8.3.305_1

Kozlov, D., 2013. The Readers of Novyi Mir: Coming to Terms with the Stalinist Past. 1st Edn., Harvard University Press, Cambridge, ISBN-10: 0674072871, pp: 442.

Lotman, Y., 1998. Semiotics of cinema and cinema esthetics issues. Iskusstvo, Petersburg.

McGann, J., 2014. A new republic of Letters: Memory and Scholarship in the Age of Digital Reproduction. 1st Edn., Harvard University Press, Cambridge, ISBN-10: 0674728696, pp: 256.

Popov, V.I., 2015. 3D Cinematography in the Cinema Art of Kazakhstan: Technological, Film Studying and Social Aspects. Am. J. Applied Sci., 12: 830-835. DOI: 10.3844 /ajassp.2015.830.835 
Rabiger, M., 2014. Directing the Documentary. 1st Edn., CRC Press, ISBN-10: 131796389X, pp: 572.

Robbe-Grillet, A., 2000. La Maison de Rendez-Vous: Novels. Symposium, Stories. St. Petersburg.

Rutten, E., J. Fedor and V. Zvereva, 2013. Memory, Conflict and New Media: Web Wars in PostSocialist States. Routledge, ISBN-10: 1136186417 , pp: 288 .

Samutina, N., 2002. Auteur intellectual cinema as a European idea. Cinematology Notes.

Sarkisova, O. and O. Shevchenko, 2014. Soviet Past in Domestic Photography: Events, Evidence, Erasure. In: Double Exposure: Memory and Photography, Shevchenko, O. (Ed.), Transaction Publishers, New Brunswick, pp: 147-174.

Sayad, C., 2016. A matter of (informed) taste. Film Criticism

Shalabayeva, G., 2012. Union of art and science languages: Methodological approaches. T.K. Zhurgenov Kazakh National Academy of Arts, Poligrafkombinat, Almaty.
Sperling, J., 2016. Art and realism in a digital age. Film Criticism.

Stoddard, M., 2016. The subject of film studies. Film Criticism.

Sturhen, M. and L. Cartwrigt, 2001. Practices of Looking: An Introduction to Visual Culture. 1st Edn., Oxford University Press, New York.

Tarkovsky, A., 2002. Sculpting in Time. In: Arseny Tarkovsky: Life of the Family and the History of Clan. Volkova, P.D. (Ed.) Eksmo-Press, Moscow.

Truffaut, F., 1985. A Certain Trend of French Cinema: An article for Cahiers du Cinema, 1954. In: François Truffaut: Masters of Foreign Cinematography, Belenky, I. (Ed.), Iskusstvo, Moscow.

Voegelin, S., 2014. Sonic Possible Worlds: Hearing the Continuum of Sound. Bloomsbury Academic, New York, ISBN-10: 162356509X, pp: 216.

Yampolsky, M., 2002. Critical moment. Cinematology Notes. 